\title{
Critical Success Factors of Organizational Performance: A Study of Small and Medium Enterprisesin Jordan
}

\author{
${ }^{1}$ AlQudah, M. K., ${ }^{2}$ Osman, A. \& Safizal, M. A \\ ${ }^{123}$ School of Business Innovation and Technopreneurship University Malaysia Perlis (UniMAP)
}

\begin{abstract}
This paper examines the human resource management practices based on organizational performance of small and medium enterprises (SMEs) in Jordan.The factors that affect quality circle and performance appraisal were also investigated. The study sample comprised 332 SMEs in Jordan. A questionnaire was developed and distributed, and the collected data were analyzed using SPSS. An overall analysis was performed based on the descriptive and correlation analyses. HR planning, training, and development significantly correlated with the organizational performance of SMEs. Several recommendations for enhancing the organizational performance of SMEs were also cited in this paper.
\end{abstract}

Keywords: quality circle, performance appraisal, organizational performance

\section{Introduction}

Organizations aim to achieve competitive advantages amid the threats of globalization. Most organizations target additional profits because of high competency requirements. Employees are required to demonstrate fair performance and to improve their capabilities. Therefore, the performance of organizations is measured according to their formulation of organizational planning. Given that human resource is one of the most important assets of an organization, implementing human resource management (HRM) practices and developing individuals to become assets of an organization are crucial. Therefore, implementing sound HRM practices in an organization may improve organizational performance (Pathak, Budhwar, Singh, \& Hannas, 2005; Delaney \& Huselid, 1995; Guest, 1997). According to Guest (1997), the HRM practices of organizations produce positive outcomes, such as high quality,highly flexible, and highly committed staff members, who can positively affect organizational performance.

Recent studies indicate that HRM practices affect organizational performance through development and behavior (Moideenkutty, Al Lamki, \& Murthy, 2011; Collins \& Smith, 2006) or attitudes and performance of employees. Organizations can increase involvement in HRM practices as well as by enhancing organizational commitment and control (Authur, 1994; Bae \& Lawler, 2000; Delaney \& Huselid, 1996; 2005; Osman, Ho, \& Galang, 2011; Guest, 1997; Pathaket al., 2005). Further, companies can develop their strengths by focusing on the internal developmentand the acquisition of the necessary skills of their present workforce. Given the limited number of studies in this area, Chand and Katou (2007) as well as Moideenkutty et al. (2011) call for additional empirical studies to investigate the relationship between HRM practices and organizational performance. When employees contribute to their organizations and continuously support their goals and objectives, organizations are required to measure the HRM practices that are embedded in their operations to ensure that the two basic concepts of person-job fit and person-organization fit can be determined (Mello, 2011).

Furthermore, to deliver outstanding service, employees must benefit from HRM functions, namely, recruitment and selection, manpower planning, job design, training and development, quality control, compensation and benefits, and performance appraisal (Dessler, 2011; Osmanet al. 2011; Dimba, 2010). This study investigates modern management practices, specifically quality circle and the influencing factors of performance appraisal. While modern management is a new concept for developing countries, such as Jordan, this concept is given more importance in this study, especially in light of the present circumstances and technological and economic variables. The multi-policy in the Jordanian public sector requires the adoption of quality circle and performance appraisal concepts from the application perspective for organizations to keep up with the rapid changes in their environment.

\section{Literature Review}

Organizational performance is determined by measuring the actual outputs of an organization against its intended outputs (i.e., goals or objectives). Previous studies report a positive relationship between organizational performance and HRM practices as well as between organizational performance and organizational outcomes, particularly in compensation, incentives, training, selective hiring, performance evaluation, and information sharing (Par \& Zhu, 2010; Delaney \& Huselid, 1996). According to Richard, 
Devinney, Yip, and Johnson (2009), organizational performance comprises three areas of company outcomes, namely, financial performance (return on assets, return on investment, and profits), product market performance (sales and market share), and shareholder return. Organizational performance refers to strategic planning, operations, finance, legal, and organizational developments. Several researchers relate organizational performance with financial performance, which involves budgets, assets, operations, products, services, and markets (Thurbin, 1994; Smith, 1999; Subramaniam, Shamsudin, \& Ibrahim, 2011; Dixon, 1991).

Some researchers identify several non-financial outputs that contribute to organizational performance, namely, management quality (De Waal \& Frijns, 2011), long-term orientation (Steiss, 2003; Guest, 1997), continuous improvement (Arsad, 2012), workforce quality (Storey, 1989), openness, and action orientation (Pathaket al., 2005). Guest (1997) identifies three factors that comprise organizational development. First, quality refers to the selection, socialization, training and development, and quality improvement programs that are constructed based on the skills and abilities of the employees. Second, commitment includes civil status, job security, internal promotion, and individualized reward system that is formulated based on the efforts or motivation of the employees. Third, flexibility covers communication, employee involvement, teamwork, organizational design, and a flexible job description that is constructed based on the role structure and perception of the employees (Guest, 1997).

\subsection{Quality Circle}

Quality circle is a quality management activity that ensures the smooth operation of an organization. Organizations evaluate the quality of their outputs by inspecting their workflows, implementing quality control and assurance strategies, and integrating business planning with strategic quality management (Hassan, 2010). The updating of documents presents a significant concern in the quality circle process, which can be facilitated by implementing a computerized system that can simplify the operations of an organization (Bell \& Omachonu, 2011). An organization can establish different quality management and control strategies based on their currentpolicies and conditions. Several organizations achieve favorable performance by implementing a structured quality circle. Quality circle requires the participation of employees as they manage the workflows of their organizations. Therefore, the success of an organization is guaranteed when its employees actively commit themselves to quality management practices.

Hassan (2010) reports that organizations that adopt quality circle outperform organizations that did not adopt such practices. The implementation of appropriate business performance measures can help quality management systems achieve results that comply with the ISO certification standards (Bell \& Omachonu, 2011). A study on the activities of technical medical personnel in military camps has identified several inaccuracies in the weight, height, visual acuity, and color vision measurements of technical soldiers. The quality assurance teams of these military camps then organized training programs to improve the performance of their technical soldiers in taking the measurements of their new recruits. Managers should also participate in the activities of quality assurance teams to monitor the performance of the recruiters (Chaiter, Palma, Machluf, Cohen, Yona, Pirogovsky, Shohat, Ytzhak, \& Ash, 2011). Moreover, researchers suggest a positive relationship between quality circle and organizational performance (Bell \& Omachonu, 2011; Chaiter et al.,2011; Arsad,2012).

\subsection{Performance Appraisal}

Performance appraisal assesses the achievement of performance objectives for a specific job within a time period. This process significantly influences the opinions of employees about themselves and about their contributions to the fulfillment of organizational objectives. Bernardin and Russel (1993) argue that the broader communication of performance appraisal policies within an organization could help employees understand the expectations of their organizations. Performance appraisal must be based on impartiality, fairness, inclusiveness, ethicality, and widely accepted standards (Webb, 2004). Frequent supervision and constant feedback can help employees realize their objectives. Dave and Wayne (2005) claim that using performance appraisal as an instrument of retaliation because of personal matters could negatively affect the future performance of employees. An effective performance appraisal must consider the involvement of employees in the setting of performance goals, the clarity of performance standards, the flexibility of the system to comply with the changing needs, and the right of employees to challenge their performance evaluation (Wu, 2005; Islam \& Rasad, 2006). Other researchers report a positive relationship between performance appraisal and organizational performance.

Lee and Lee (2007) state that an effective performance appraisal system could enhance the productivity and quality of employees. Meanwhile, Sang (2005) argues that a complete, impartial, and customer-targeted performance appraisal system could improve the performance of employees. As cited by Khan (2010), Rahman 
(2006) reports that a comprehensive performance appraisal system could foster the commitment of employees to their organizations. Brown and Heywood (2005) identify a positive relationship between an effective performance appraisal system and an enhanced productivity of organizations. Regular supervision and feedback between employees and supervisors can strengthen the employee-employer relationship (Cook \& Crossman, 2004). Performance appraisal can also offer employees with opportunities for promotion, recognition, and career development (Larsson et al., 2007). Most researchers suggest a positive relationship between quality circle and organizational performance (Abang, 2009; Kundu, 2007; Osman, 2011; Khan, 2010).

\section{Research Hypotheses}

$\mathrm{H}_{1}$ : A positive relationship exists between quality circle and organizational performance of SMEs in Jordan.

$\mathrm{H}_{2}$ : A positive relationship exists between performance appraisal and organizational performanceof SMEs in Jordan.

\subsection{Research Findings}

Respondents answered the items in the questionnaire on a five-point Likert scale, with 5 denoting "always" and 1 denoting "never." Mean scores of less than 2.33 were considered weak, mean scores ranging between 2.76 and 3.94 were considered moderate, and mean scores of more than 3.67 were considered high.

Table1. Descriptive Results

\begin{tabular}{llccc}
\hline Ser. & Variables & Mean score & Standard deviations & CronbachAlpha \\
\hline 1 & Quality circle & 2.95 & .785 & .875 \\
\hline 2 & Performance appraisal & 2.91 & .730 & .882 \\
\hline
\end{tabular}

Table 1 shows that quality circle obtained the highest mean score of 2.95 . This result suggests that the planning processes within the SMEs in Jordanare well established. In addition, HR staff members are well versed in the rules and procedures, and are experienced and competent in the quality circle. Both quality circle and performance appraisal indicate acceptable reliability levels at .875 and .882 , respectively.

\subsection{Hypotheses Testing}

To test the hypotheses, a simple regression analysis was performed on the resource management activities in general and the strategic planning practice in particular. Table 2 shows the correlation coefficient, $\mathrm{R} 2, \mathrm{~F}$ value, and significance level of the variables.

Table2. Summary of Regression Analysis

\begin{tabular}{llccc}
\hline Ser. & Variables & Beta & Correlation & Significance level \\
\hline 1 & Quality circle & .121 & .527 & .014 \\
\hline 2 & Performance appraisal & .232 & .568 & .000 \\
\hline
\end{tabular}

Table 2 presents the multiple regression coefficients $(\mathrm{R})$ independent variables to the organizational performance as the dependent variable. All variables are significant ( $p$ <.05). In terms of beta values, the highest beta coefficient corresponds to performance appraisal, where (Beta $=.232$ ). This result indicates that performance appraisal made the strongest contribution to explain the dependent variable (organizational performance). The second highest beta value is seen in quality circle with the value of (Beta =.121). As shown in correlation results, the highest correlation value is performance appraisal $(\mathrm{r}=.568 ; \mathrm{p}<.05)$, and followed by quality circle $(\mathrm{r}=.527 ; \mathrm{p}<.05)$. The results indicate that all the variables have positive relationship and statistically significant at $\mathrm{p}<.05$.

Table3. Summary of Hypotheses Testing

\begin{tabular}{|c|c|c|}
\hline Hypotheses & $\begin{array}{l}\text { Correlation } \\
\text { coefficient }\end{array}$ & Result \\
\hline $\begin{array}{l}\mathrm{H}_{1}: \text { A positive relationship exists between quality circle and organizational } \\
\text { performance of SMEs in Jordan. }\end{array}$ & .527 & Accepted \\
\hline $\begin{array}{l}\mathrm{H}_{2}: \quad \text { A positive relationship exists between performance appraisal and } \\
\text { organizational performance of SMEs in Jordan. }\end{array}$ & .568 & Accepted \\
\hline
\end{tabular}


The results of the hypotheses testing (Table 3)indicate that the independent variables significantly correlate with the dependent variable, and thus confirming the significant association between the variables. The analysis suggests lack of multicollinearity in this study because the correlation coefficient is less than 0.80 .

\section{Recommendations}

Human resources refer to people whose knowledge, skills, and abilities are utilized to create and to deliver effective services. Human resource is considered as the greatest resource of an organization. An effective quality circle attracts the right quality and quantity of people, develops the knowledge, skills, and abilities of employees, and retains employees within the organization. To improve further the system of SMEs in Jordan, these organizations must utilize modern technology for strategically planning and developing their human resources. Moreover, a performance appraisal program must be implemented to enhance the capabilities of employees and of SMEs in Jordan. Investing in the improvement of the knowledge and skills of employees enables SMEs in Jordan to develop highly productive and effective employees.

\section{References:}

[1]. Arsad, M. (2012). Human Resource Management Practices and Organizational Performance: A Study on Administrators in Universiti Teknologi Mara. (Unpublished MSc Dissertation).Universiti Utara Malaysia.

[2]. Aurthur, J. (1994). Effects of HR systems on manufacturing performance and turnover. Academy of Management Journal, 37, 670687.

[3]. Bae, J. \& Lawler, J. J. (2000). Organisational and HRM strategies in Korea: Impact on firm performance in an emerging economy. Academy of Management Journal, 43, 502-517.

[4]. Bell, M. \& Omachonu, V. (2011). Quality system implementation process for business success. International Journal of Quality \& Reliability Management, 28(7), 723-734.

[5]. Brown, M. \& Heywood, J. S. (2005). "Performance appraisal systems: determinants and change", British Journal of Industrial Relations, 43(4), pp.659-679.

[6]. Chaiter, Y., Palma, E., Machluf, Y., Cohen, A. and Yona, A., Pirogovsky, A., Shohat, T., Ytzhak, A. \& Ash, N. (2011). Qualityassuring intervention for technical medical staff at medical committees. International Journal of Health Care Quality Assurance, 24(1), 19-30.

[7]. Chand M. \& Katou A.A. (2007). The Impact of HRM practices on organisational performance in the Indian hotel industry. Employee Relations, 6, 576-594.

[8]. Collins, A.B. (2007). "Human resources: a hidden advantage?', International Journal of Contemporary Hospitality Management, Vol. 19 No. 1, pp. $78-84$

[9]. Dave, U., \& Wayne, B. (2005). HRM value of proposition, Boston, Harvard Business School.

[10]. De Waal, A. \& Frijns, M. (2011). Longitudinal research into factors of high performance: the follow-up case of Nabil Bank. Measuring Business Excellence, 15(1), 4-19.

[11]. Delaney, J. T. \& Huselid, M. A. (1996). The impact of human resource management practices on perceptions of organizational performance. Academy of Management Journal, 39(4), 949-969.

[12]. Dessler, G. (2011). Human Resource Management. USA: Pearson Education.

[13]. Dimba, B. A. (2010). Strategic human resource management practices: effect on performance. African Journal of Economic and Management Studies, 1(2), 128-137.

[14]. Dixon, N. M. (1991). Helping US HR professionals into action learning. Action Learning in Practice, 2nd edition. UK: Gower, Eldershot.

[15]. Guest, D. E. (1997). Human Resource Management and Performance: review and research agenda. The International Journal of Human Resource Management, 8(3).

[16]. Hassan, A. (2010). Linking quality assurance to human resource management: A study of SMEs in Malaysia. International Journal of Quality \& Reliability Management. 27(6), 641-657.

[17]. Islam, R. \& Rasad, S.M. (2006). "Employee performance evaluation by the AHP: A case study". Asia Pacific Management Review, 11 (3), pp. 163-176.

[18]. Khan, M. (2010). Effects of Human Resource Management Practices Organizational Performance - An Empirical Study of Oil and Gas Industry in Pakistan. European Journal of Economics, Finance and Administrative Sciences. (24), 157-175.

[19]. Larsson. R, Brousseau. K, Kling, K \& Sweet, L. (2007). "Building motivational capital through career concept and culture fit: the strategic value of developing motivation and retention", Career Development International, 12(4), pp. 361-381.

[20]. Lee, Feng-Hui, \& Lee, Fzai-Zang. (2007). "The relationships between HRM practices, Leadership style, competitive strategy and business performance in Taiwanese steel industry", Proceedings of the 13th Asia Pacific Management Conference, Melbourne, Australia, 2007, 953-971.

[21]. Mello J.A. (2011). Strategic Management of Human Resource. Canada: South- Western, Cengage Learning.

[22]. Moideenkutty. U, Al Lamki. A \& Murthy Y.S.R. (2011). HRM practices and Organisational Performance in Oman. Personnel Review, 40(2), 239-251.

[23]. Osman, I., Ho, C. F.\& Galang, M. C. (2011). The relationship between human resource practices and firm performance: an empirical assessment of firms in Malaysia. Business Strategy Series, 12(1), 41-48.

[24]. Osman, I., Ho, C. F.\& Galang, M. C. (2011). The relationship between human resource practices and firm performance: an empirical assessment of firms in Malaysia. Business Strategy Series, 12(1), 41-48.

[25]. Par \& Zhu, Y. (2010). The effect of the HR practices on firm performance in Chinese SMEs: An empirical study in manufacturing sector. (Published MSc Thesis). Library and Archives of Canada.

[26]. Pathak, R. D., Budhwar, P. S., Singh, V. \& Hannas, P. (2005). Best HRM practices and employees' psychological outcomes: A study of shipping companies in Cyprus. South Asian Journal of Management, 12(4), 7. 
[27]. Rahman, S. A. (2006). "Attitudes of Malaysian teaches towards a performance appraisal system", Journal of Applied Social Psychology, 36(12), pp. 3031-3042.

[28]. Richard, P. J., Devinney, T. M., Yip, G. S. \& Johnson, G. (2009). Measuring organizational performance: Towards methodological best practice. Journal of Management, 35(3), 718-804.

[29]. Richard, P. J., Devinney, T. M., Yip, G. S. \& Johnson, G. (2009). Measuring organizational performance: Towards methodological best practice. Journal of Management, 35(3), 718-804.

[30]. Russell, J.S., Terborg, J.R. \& Powers, M.L. (1995). "Organisational Performance and Organisational Level Training and Support", Personnel Psychology, 38, pp. 849-63.

[31]. Sang, C. (2005). "Relationship between HRM practices and the perception of organizational performance, roles of management style, social capital, and culture: comparison between manufacturing firms in Cambodia and Taiwan. (Unpublished Doctoral Dissertation) National Cheng Kung University, Tainan, Taiwan.

[32]. Steiss, A. W. (2003). Strategic management for public and non-profit organisations. New York: Taylor and Francis Inc.

[33]. Storey, J. (1989). New perspectives on HRM. International Thomson Business Press, UK.

[34]. Thurbin, P. J. (1994). Implementing the learning organization: The 17th days programme. UK: Pitman Publishing.

[35]. Webb, J. (2004). Putting Management Back into Performance: A Handbook for Managers and Supervisors, Australia: Allen \& Unwin.

[36]. Wu, H.L. 2005. "A DEA approach to understanding the performance of Taiwan's steel industries 1970-1996", Asia Pacific Management Review, 10 (6), pp. 349-356. 